\title{
Implicit and explicit boundaries of belonging: : indigenous and minority identities
}

\section{Nieminen, Kati}

Edward Elgar

2019-10

Nieminen , K 2019 , Implicit and explicit boundaries of belonging: indigenous and minority identities . in S M Sterett \& L D Walker (eds), Research Handbook on Law and Courts . , 26 , Research Handbooks in Law and Politics , Edward Elgar , pp. 365-278 . https://doi.org/10.4337/9781788113205.00

http://hdl.handle.net/10138/313930

https://doi.org/10.4337/9781788113205.00036

unspecified

acceptedVersion

Downloaded from Helda, University of Helsinki institutional repository.

This is an electronic reprint of the original article.

This reprint may differ from the original in pagination and typographic detail.

Please cite the original version. 
This is a draft chapter. The final version is available in Research Handbook on Law and Courts edited by Susan M. Sterett \& Lee D Walker, published in 2019, Edward Elgar Publishing Ltd http://dx.doi.org/10.4337/9781788113205

The material cannot be used for any other purpose without further permission of the publisher, and is for private use only. 


\title{
Implicit and Explicit Boundaries of Belonging
}

\author{
Kati Nieminen ${ }^{1}$
}

\begin{abstract}
This Chapter discusses the role of the courts in drawing boundaries of identity and belonging in the majority and minority populations and indigenous peoples. The topic is approached with two examples. First, the role of the European Court of Human Rights in the so called headscarf debate is discussed from the perspective of (re)producing the French citizen subject in the case of S.A.S. v. France. It is argued that while on the surface the case concerns the relationship between individual rights and general interests of the society, implicitly the Court participates in a debate over belonging. The second example examines the role of the Finnish Supreme Administrative Court in determining who belongs in the Sámi people, which is the only recognized indigenous people in the European Union. In this example the role of the court to determine belonging is explicit, as in Finland it is ultimately for the Supreme Administrative Court to determine who can be included in the Sámi Parliament's electoral roll. The struggles in the examples are opposite: while the Sámi struggle for preserving their indigenous identity and resist assimilating to the majority population, the Muslim woman wearing the full-face veil invites the French society to recognize her as one of 'us' and to redefine the citizen subject. In both examples, however, the repercussions of the law are profound, as they illustrate the ways in which courts participate in debates over subjectivity and belonging.
\end{abstract}

\section{Introduction}

This Chapter discusses the role of the courts in drawing boundaries of identity and belonging in the majority and minority populations and indigenous peoples ${ }^{2}$. The topic is approached with two

\footnotetext{
${ }^{1}$ Kati Nieminen (M.A., LL.D.) is a postdoctoral researcher at the Institute of Criminology and Legal Policy at the University of Helsinki, Finland. Her research covers areas such as legal policy and access to justice. ORCID: 0000-0001-9369-8599

${ }^{2}$ While there are similarities between the situation and rights of indigenous peoples and ethnic and cultural minorities, the recent initiatives at the international level have moved in the direction of acknowledging the claim of many indigenous peoples of the differences between indigenous and minority populations. See Larry Chartrand, 'Re-Conceptualizing
} 
examples. First, the role of the European Court of Human Rights (ECtHR) in the so called headscarf debate is discussed from the perspective of (re)producing the French citizen subject in the case of

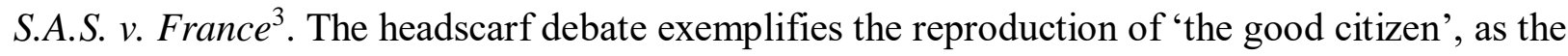
Islamic headscarf and particularly the full-face veil have become markers of non-belonging in some European countries. Analysis of the Court's case law suggests that because a Muslim woman covering her face represents 'the Other', her self-identification both as a devout Muslim and as a 'Western' citizen is rejected. The headscarf cases offer glimpses of the characteristics implicitly required from the good citizen subject - the one on top of the hierarchies of citizenship ${ }^{4}-$ as the cases force the law to explicate them.

The second example examines the role of the Finnish Supreme Administrative Court in determining who belongs in the Sámi people, which is the only recognized indigenous people in the European Union. The question of belonging relates to indigenous peoples in two ways: one concerning the relationship between the indigenous people and the state, and the other concerning the relationship between the indigenous people and an individual identifying with the people. The universal question is, who is indigenous? It is often both a question of identity and recognition as well as a question of rights and resources. The question of who is indigenous is a complicated one, as indigenous people have often been actively assimilated in the majority population. Furthermore, it is not clear what exactly is it that defines the indigenous people: is it the bloodline, the language, the traditional way of life, all of them together or something else?

This Chapter discusses the way in which the courts deal with the loaded question of belonging, which relates to the complicated issues of rights, identities and power relations of indigenous peoples, minorities and majorities. In conclusion it is argued that in drawing the boundaries of belonging the role of the courts can be both implicit and explicit. On the surface the so called headscarf cases concern individual rights such as freedom of religion, freedom of expression and prohibition of discrimination, whereas the question of belonging is present only implicitly. The Court nevertheless indirectly participates in reproducing the 'good citizen subject', and thus the dynamics of inclusion and exclusion are present in the Court's decision making. Concerning the

Equality: A Place for Indigenous Political Identity' (2001) 19 Windsor Yearbook of Access to Justice 248, 248-249; Sharon Helen Venne (1998) as cited in ibid.

${ }^{3}$ S.A.S. v. France ECHR 2014.

${ }^{4}$ See Siobhán Mullally, 'Gender equality, citizenship status, and the politics of belonging' in Martha Albertson Fineman (ed.), Transcending the Boundaries of Law. Generations of Feminism and Legal Theory (Routledge 2011) 201; Sherene Razack, 'Imperilled Muslim Women, Dangerous Muslim Men and Civilised Europeans: Legal and Social Responses to Forced Marriages' (2004) 12 (2) Feminist Legal Studies 129, 155. 
question of who is indigenous, on the other hand, the courts' role is, in some jurisdictions, to draw explicit lines of inclusion and exclusion. In both examples the repercussions of the law are profound, as they illustrate the ways in which courts participate in debates over subjectivity and belonging. The struggles in the examples are opposite: while the Sámi struggle for preserving their indigenous identity and resist assimilating to the majority population in Finland, the Muslim woman wearing the full-face veil invites the French society to recognize her as one of 'us' and to redefine the citizen subject.

\section{Implicit boundaries: the 'headscarf cases' and the question of belonging}

Religious symbols, and Islamic clothing in particular, have been at the center of multiple cases of the European Court of Human Rights during the past twenty years ${ }^{5}$, yet the issue seems far from exhausted. ${ }^{6}$ In the following the case of S.A.S. v. France is discussed from the perspective of belonging. While the ECtHR has given many rulings concerning the Islamic headscarf and the fullface veil, S.A.S. v France is the case the Court refers to in its' more recent rulings, and it therefore remains the most central of the cases. ${ }^{7}$

Generally speaking the Court's assessment can be divided in two phases: first, the Court determines whether there has been a breach of a freedom enshrined in the European Convention on Human

\footnotetext{
${ }^{5}$ See e.g. Ahmet Arslan v Turkey App no 41135/98 (ECHR 23 February 2010); Dahlab v Switzerland ECHR 2001-V; Eweida and others $v$ The United Kingdom ECHR 2013; Lautsi v Italy ECHR 2011; Leyla Şahin v Turkey ECHR 2005XI. The relationship between the so called headscarf cases and the ECtHR cases concerning other types of religious clothing and symbols is discussed e.g. in Kati Nieminen, The Law, the Subject and Disobedience - Inquiries into Legal Meaning Making (University of Helsinki 2017); 'Disobedient Subjects - Constructing the Subject, the State and Religion in the European Court of Human Rights' (2015) Social Identities 21.

6 See for example Angelique Chrisafis, 'French burkini ban row escalates after clothing incident at Nice beach' (The Guardian, 25 August 2016) https://www.theguardian.com/world/2016/aug/24/french-burkini-ban-row-escalatesclothing-incident-woman-police-nice-beach accessed 19 October 2017: Lizzie Dearden, 'Austrian parliament passes burqa ban seeing Muslim women face $£ 130$ fines for wearing full-face veils' (Independent 18 May 2017) http://www.independent.co.uk/news/world/europe/austria-burqa-ban-parliament-fines-150-full-face-veils-muslimislam-niqabs-public-transport-a7742981.html accessed 19 October 2017; Amanda Taub, 'France's "Burkini” Bans Are About More Than Religion or Clothing' (The New York Times 18 August 2016) https:/www.nytimes.com/2016/08/19/world/europe/frances-burkini-bans-are-about-more-than-religion-or-clothing.html accessed 19 October 2017.

${ }^{7}$ The most recent of the cases concerning the full-face veil are Dakir v. Belgium App no 4619/12 (ECHR 11 July 2017) and Balkacemi and Oussar v Belgium App no 37798/13 (ECHR 11 July 2017). The Court's argumentation in these cases concerning Article 9 of the Convention follows the pattern established in S.A.S v. France; see Marcella Ferri, 'Belkacemi and Oussar v Belgium and Dakir v Belgium: the Court again addresses the full-face veil, but it does not move away from its restrictive approach' (Strasbourg Observers 25 July 2017) https://strasbourgobservers.com/2017/07/25/belkacemiand-oussar-v-belgium-and-dakir-v-belgium-the-court-again-addresses-the-full-face-veil-but-it-does-not-move-awayfrom-its-restrictive-approach/\#more-3838 accessed 7 May 2018.
} 
Rights, such as Article 9 protecting the freedom of religion. If the Court finds a breach, it then proceeds to assess whether the limitation of the freedom is legitimate; whether it pursues a legitimate aim, whether it is prescribed by law and whether it is proportionate and 'necessary in a democratic society'.

In S.A.S. v. France the Court assessed the legitimacy of a ban introduced in 2011 prohibiting anyone from concealing their faces in public. The French Government's insistence that the ban was neutral in that it did not explicitly target Muslim women seems disingenuous in the light of the drafting history of the ban, recited in S.A.S. ${ }^{8}$ For example the parliamentary commission established for drafting a report on 'the wearing of the full-face veil on national territory' found in 2010 that concealing the face is 'at odds with the values of the Republic', namely those of liberty, equality, and fraternity. ${ }^{9}$ Furthermore, in 2011 the National Assembly adopted unanimously a resolution 'on attachment to respect for Republic values at the time when they are being undermined by the development of radical practices'. ${ }^{10}$ These 'radical practices' that are incompatible with the values of the Republic, according to the resolution, include the wearing of the full veil. ${ }^{11}$ A breach of the prohibition on covering of the face in public is punishable by a fine and in addition may be combined with an obligation to follow a citizenship course, which again indicates that the ban is drafted with a 'foreign subject' in mind - the 'real' French citizen, the sanction seems to suggest, does not wear the full-face veil. ${ }^{12}$

The current aversion towards the Islamic headscarf and full-face veil in France did not develop overnight. In fact, the full-face veil ban is a peak of a long process of politicization of Islamic clothing. The so called 'Muslim headscarf affair' in France began in 1989, when the director of a secondary school in Creil decided to exclude three girls for wearing the headscarf, as he considered that the headscarf undermined the secularity principle, laïcité. The Consel d'Etat found otherwise stating that the pupils could make their own decisions on the matter. In 1994 the issue resurfaced when the Minister of Education declared the headscarf as a 'conspicuous sign' reflecting a proselytising attitude. Still, the Conseil d'Etat maintained its previous position. It was only at the

\footnotetext{
${ }^{8}$ See also Dakir v. Belgium [8-21].

${ }^{9}$ S.A.S. v. France, paras [15], [17].

${ }^{10}$ S.A.S. v. France [24].

${ }^{11}$ Ibid.

12 The question of discrimination was deflected by the Court. On one hand the Court acknowledged that despite the fullface veil ban was neutrally worded, it did have a disproportionally prejudicial effect on Muslim women. On the other hand, however, the Court regarded that this discriminatory effect was justified based on its legitimate aim. Kati Nieminen, 'Procedural and De-Contextualised Approach to Discrimination in the European Court of Human Rights: The Case of S.A.S. v France' (2018) Unpublished manuscript.
} 
beginning of 2000 when the debated became heated and finally led to the prohibition of the headscarf in public schools and later to the full-face veil ban in all public places. ${ }^{13}$

In S.A.S v. France the applicant challenged the full-face veil ban arguing, among other things, that it violated her freedom of religion. The French Government, on the other hand, argued that the ban pursued the legitimate aim of protecting the rights of others by ensuring the respect for minimum set of shared values. According to the Government the face plays a significant role in human interaction, and covering of the face indicates breaking of the social tie and refusal of the principle of 'living together'. ${ }^{14}$ The Court was persuaded by the Government's argumentation, and found no violation of any of the Convention articles. After dismissing the Government's assertion that the ban aimed at promoting gender equality and human dignity, the Court accepted that what the Government had described as 'respect for the minimum requirements of life in society' or of 'living together' could be linked to the aim of the 'protection of the rights and freedoms of others' - an aim which could be accepted as legitimate by the Court. The Court concluded that it was able to accept that the French government regarded the full-face veil 'a barrier raised against others' and that it breached the 'right of others to live in a space of socialization which made living together easier'. Finally, the Court came to the conclusion that this aim was both necessary and proportionate to the aim pursued taking into consideration the margin of appreciation granted for the states to interpret the Convention Articles in the context of their respective circumstances. ${ }^{15}$

The Government's argumentation rested on a particular idea of a French citizen and the French society. According to Thomas, the French conception of laïcité, the principle of secularity, 'is not a mere "boundary keeper" that should be limited to ensuring that the separation between the state and religions is respected', but 'tied to the republican model of citizenship's relation to group membership'. ${ }^{16}$ Thus the way the Government defended the full-face veil ban in S.A.S. v. France

\footnotetext{
${ }^{13}$ See Patrick Simon and Valérie Sala Pala, "'We are not all multiculturalists yet" France swings between hard integration and soft anti-discrimination' in Steven Vertovec and Susanne Wessendorf (eds), The Multiculturalism Backlash. European discourses, policies and practices (Routledge 2010); Kati Nieminen, The Law, the Subject and Disobedience - Inquiries into Legal Meaning Making (University of Helsinki 2017).

${ }^{14}$ S.A.S. v. France [82].

15 S.A.S. v. France [122].The Court's acceptance of 'living together' as a legitimate aim pursued by the ban has been criticized by many legal scholars. See Saïla Ouald Chaib and Lourdes Peroni, 'S.A.S. v. France: Missed Opportunity to Do Full Justice to Women Wearing a Face Veil' (Strasbourg Observers, 3 July 2014) https://strasbourgobservers.com/2014/07/03/s-a-s-v-france-missed-opportunity-to-do-full-justice-to-women-wearing-aface-veil/ accessed 19 October 2017; Effie Fokas 'Directions in Religious Pluralism in Europe: Mobilizations in the Shadow of European Court of Human Rights Religious Freedom Jurisprudence’ (2015) 4(1) Oxford Journal of Law and Religion 54.

${ }^{16}$ In France and in the US the secularity principle is understood differently; whereas Americans historically sought to protect religion from the state, France's combat sought to free state from undue religious influence. Elaine R. Thomas, Immigration, Islam, and the Politics of Belonging in France: A Comparative Framework (University of Pennsylvania Press 2011) 186-7.
} 
can be linked to the way the relationship between an individual and the state is construed in France. ${ }^{17}$

The applicant, who attempted to combine the subjectivities of an autonomous, democratic 'Western' subject and that of a devout Muslim covering her face challenged the implicit ideas of belonging underlying the Government's assertions. She argued, first, that reciprocal exposure of faces is not fundamental in the French society, because not all French minorities share the view. Her argument can be understood as an attempt to challenge the Government's implication that not accepting the principle of reciprocal exposure of faces indicates non-belonging in the French community. ${ }^{18}$ An interesting aspect of the Court's argumentation is that rather than the applicant's own understanding of what the full-face veil signify to her, the Court emphasised the way the veil might be perceived by others who may not wish 'to see practices which would fundamentally call into question the possibility of (...) living together'. ${ }^{19}$ Why was it important for the French Government to protect those others from their own perception? Following Laegaard it can be argued that the importance of the face is not merely a practical claim concerning the possibility of interpersonal interaction, but a stronger claim concerning individuality, subjectivity and belonging. ${ }^{20}$ The Government constructed the Muslim woman both as oppressed by Muslim men and as an aggressor threatening the national values. As Evans explains, not only is the aggressor a threat, but so is the perceived victim, as by her mere existence she questions the liberal, egalitarian order. ${ }^{21}$ Furthermore the veiled woman cannot be included in 'us', because that would deconstruct the distinction between 'us' and 'the Other', therefore deconstructing not only 'the Other', but 'us' as well. ${ }^{22}$

In this context it is possible to see S.A.S. as an example of racialization of Muslims. Racialization means 'extending racial meaning to relationships, groups or practices, such as cultural traits and

\footnotetext{
${ }^{17}$ About lä̈cité in France see also Eoin Daly, 'Laïcité in the Private Sphere? French Religious Liberty after the BabyLoup Affair' (2016) 5 Oxford Journal of Law and Religion 211; Stéphanie Hennette Vauchez, 'Is French laïcité Still Liberal? The Republican Project under Pressure (2004-15)' (2017) 17 Human Rights Law Review 285.

18 See Murat Akan, 'Laïcité and multiculturalism: the Stasi Report in context' (2009) 60(2) The British Journal of Sociology 237; Myriam Hunter-Henin, 'Why the French don't like the burqa: Laïcité, national identity and religious freedom’ (2012) 61(3) International \& Comparative Law Quarterly 613; Sune Laegaard, 'Burqa Ban, Freedom of Religion and "Living Together"' (2015) 16(3) Human Rights Review 203; Elaine R. Thomas, Immigration, Islam, and the Politics of Belonging in France: A Comparative Framework (University of Pennsylvania Press 2011).

${ }^{19}$ S.A.S. v. France [122]; see also dissenting opinion in S.A.S. v. France ECHR 2014.

${ }^{20}$ Sune Laegaard, 'Burqa Ban, Freedom of Religion and "Living Together"' (2015) 16(3) Human Rights Review 203.

${ }^{21}$ Carolyn Evans, 'The Islamic Scarf' in the European Court of Human Rights' (2006) 7(1) Melbourne Journal of International Law 52.

${ }^{22}$ See Edward W. Said, Orientalism: Western Conceptions of the Orient (Penguin Books 1995); Kati Nieminen, The Law, the Subject and Disobedience - Inquiries into Legal Meaning Making (University of Helsinki 2017) 17.
} 
religion, which previously have not been associated with race'. ${ }^{23}$ According to Selod and Embrick, racialization should not be understood simply as a process of creating new racial categories, but also as a mutating and changing process in which groups are rejected from 'whiteness' ${ }^{24}$ Rather than a natural category based on biological differences or skin tone, race can thus be understood as a category constantly being formed, incessantly evolving and maintained in the society and its institutions. In fact, race and racism have never been simply about the visible traits of the human body. Rather, race, religion and culture have always been inseparably intertwined and served as a basis for organizing people in social, economic and political hierarchies, which in turned have been used for legitimating colonialism, discrimination and violence against 'the Other'. ${ }^{25}$

The experiences of Muslims vary, of course, according to multiple factors, as there is no single Muslim identity. One such factor is gender. The experiences of Muslim women and men, and the way they are perceived by others, are different. Therefore women and men also experience racialization differently. Whereas Muslim men are often viewed as potential terrorists and treated with suspicion, Muslim women are, especially if they are wearing for example hijab or niqab, viewed as a cultural threat to the 'Western' society and its ideals of equality. ${ }^{26}$ The perception seems to be that the white, Western French citizen subject is being undermined by racialized Muslims, and thus it can be argued that the ban on the Islamic headscarf and the full-face veil are attempts to draw the boundaries of whiteness. ${ }^{27}$ Even the status of a citizen in and of itself is not a guarantee of belonging in a community; research shows that even Muslims who are citizens can be racialized and discursively excluded from 'us' and positioned low on the racial hierarchy, as their religious identity is seen as incompatible with belonging. ${ }^{28}$

\footnotetext{
${ }^{23}$ Michale Omi and Howard Winant, Racial Formation in the United States: From the 1960s to the 1990s (Routledge 1986) 64; Saher Selod and David G. Embrick, 'Racialization and Muslims: Situating the Muslim Experience in Race Scholarship' (2013) 7:8 Sociology Compass 644, 647.

${ }^{24}$ Saher Selod and David G. Embrick, 'Racialization and Muslims: Situating the Muslim Experience in Race Scholarship' (2013) 7:8 Sociology Compass 644, 652.

${ }^{25}$ Charles W. Mills, The Racial Contract (Cornell University Press 1999) 21-3, 30; Saher Selod and David G. Embrick, 'Racialization and Muslims: Situating the Muslim Experience in Race Scholarship' (2013) 7:8 Sociology Compass 644, 646-7; Steve Garner and Saher Selod, 'The Racialization of Muslims: Empirical Studies of Islamophobia' (2015) 41:1 Critical Sociology $9,12-3$.

${ }^{26}$ See for example Sherene Razack, Casting Out: The Eviction of Muslims from Western Law and Politics (University of Toronto Press 2008); Saher Selod and David G. Embrick, 'Racialization and Muslims: Situating the Muslim Experience in Race Scholarship' (2013) 7:8 Sociology Compass 644.

27 See Saher Selod and David G. Embrick, 'Racialization and Muslims: Situating the Muslim Experience in Race Scholarship' (2013) 7:8 Sociology Compass 644, 651-2.

${ }^{28}$ Steve Garner and Saher Selod, 'The Racialization of Muslims: Empirical Studies of Islamophobia' (2015) 41:1 Critical Sociology 9, 16; Michale Omi and Howard Winant, Racial Formation in the United States: From the 1960s to the 1990s (Routledge 1986).
} 
The background of the so called headscarf debate in France is directly linked to the realization in the 1980 's that immigration was changing the face of the society. ${ }^{29}$ While groups of the French left envisioned a new, more inclusive citizenship which would renew the ideas of political membership, many others equated what they perceived a crisis of assimilation with a crisis of the nation. ${ }^{30}$ Thomas explains that despite their differences, competing political interpretations of new social developments such as immigration share the idea of the nation state as the favoured form of political community, which then has been reflected in the policies concerning public recognition of cultural and religious differences. ${ }^{31}$

What then, is the role of the European Court of Human Rights in reproducing a racialized understanding of belonging in S.A.S. v. France? On the surface the Court examined the extent of freedom of religion in relation to the neutrality of the public space in accordance with the principle of laïcité. Implicitly, however, the Court determined that ultimately wearing a full-face veil was not just an expression of personal belief, but a 'barrier raised against others' signifying non-belonging and as such incompatible with the French way of life. ${ }^{32}$ The Court's legal evaluation of the case rests on the idea that it is, in certain circumstances, within the powers of the state to secure the conditions it considers essential for 'living together in diversity'. While the Court did not directly address the drafting history and the social context of the ban, its argumentation implicitly reproduces the politicized image of a Muslim woman and draws the boundaries of belonging in the French society.

\section{Explicit boundaries: Sámi indigenous identity and belonging}

The question of belonging to an indigenous people is not an easy one. Often assimilationist practices have effaced the external markers of indigeneity and language, and ancestry does not, in itself, offer a solution to the question. ${ }^{33}$ The significant international agreements defining the rights of indigenous peoples are Convention no. 169 in Indigenous and Tribal Peoples by the International Labour Organization (ILO) from 1989 and the United Nations Declaration on the Rights of

\footnotetext{
${ }^{29}$ Elaine R. Thomas, Immigration, Islam, and the Politics of Belonging in France: A Comparative Framework (University of Pennsylvania Press 2011) 53.

${ }^{30}$ Ibid. $53-5$.

${ }^{31}$ Ibid. 76.

${ }^{32}$ S.A.S. v. France 2014 [122].

${ }^{33}$ See for example Lina Gaski, 'Sami Identity as a Discursive Formation: Essentialism and Ambivalence' in Henry Minde (ed.), Indigenous Peoples: Self-Determination Knowledge Indigeneity (Eburon Academic Publishers 2008).
} 
Indigenous peoples by the General Assembly in 2007. ${ }^{34}$ The ILO Convention no. 169 applies to 'tribal peoples in independent countries' who identify themselves as indigenous peoples, whose social, cultural and economic conditions distinguish them from the other sections of the national community, and who have historical continuity or association with a given region prior to conquest or colonization. ${ }^{35}$

The Convention does not, however, provide a definition of indigenous peoples in general, nor does it comment on the question of belonging of an individual to an indigenous people. In this respect the ILO Convention no. 169 is complemented by United Nations' special reporter José Martinez Cobo's report from 1986 on the discrimination of indigenous peoples, which describes both grouplevel and individual recognition of indigeneity. ${ }^{36}$ Although the prevailing view is that there is no need for a formal, universal definition of indigeneity, Martinez Cobo's definitions are often used for practical purposes. According to Martinez Cobo's group-level definition, those communities and peoples who still have continuous historical connection to the societies preceding colonization, who developed on areas populated by these peoples and who consider themselves as clearly separate from other societal structures currently prevailing in the area, are indigenous. In addition, indigenous peoples are not in a ruling position in the modern society and they want to maintain, develop and transmit their way of life and identity to the future generations. Martinez Cobo's individual-level definition requires first, that a person self-identifies as a member of an indigenous people and second, that the indigenous people acknowledges and accepts that person as their member. The United Nations Declaration states in Article 9 that 'Indigenous peoples and individuals have the right to belong to an indigenous community or nation, in accordance with the traditions and customs of the community or nation concerned. No discrimination of any kind may arise from the exercise of such right' ${ }^{37}$ Thus the international law recognizes firstly the right of indigenous peoples to be recognized by the states, and secondly the right of an individual to be recognized as indigenous - but also the right of the indigenous people to decide who belongs to the

\footnotetext{
${ }^{34}$ Finland has not ratified the ILO Convention No. 169. Despite eight years of negotiations between the Sámi Parliament and the Government of Finland, the Parliament shelved the indigenous rights agreement in 2015. Behind the decision not to proceed with ratification was a disagreement over what ratification would require in terms of recognizing the land rights of the Sámi people. See Veli-Pekka Lehtola, Saamelaiskiista: Sortaako Suomi Alkuperäiskansaansa? (Into, 2015) $186-8$.

${ }^{35}$ ILO Convention No. 169: Indigenous and Tribal Peoples Conventions (5 September 1991) Article 1.

36 José R. Martinez Cobo, 'Study of the problem of discrimination against indigenous populations' Volume 1, E/CN.4/Sub.2/1986/7.

37 United Nations Declaration on the Rights of Indigenous Peoples (A/RES/61/295) available at http://www.un.org/esa/socdev/unpfii/documents/DRIPS_en.pdf.
} 
people. ${ }^{38}$ As is discussed below, in Finland the ambiguity in the indigenous peoples definition has caused tension.

The Sámi people is the only recognized indigenous people within the European Union. The region inhabited by the Sámi, Sápmi, expands over Central Norway and Sweden to the Northern Finland and Kola Peninsula in Russia. Altogether there are about 100000 Sámi people, of whom less than 10000 are living in Finland. ${ }^{39}$ Finland's Sámi population consists of three groups whose traditions and languages differ from each other, namely the Northern-Sámi, Inari Sámi, and Skolt Sámi. The cultural and linguistic autonomy of the Sámi within the homeland area is enshrined in the Finnish Constitution, and the Act on the Sámi Parliament obliges the authorities to negotiate with the Sámi on all extensive and important questions that can directly or distinctly influence the position of the Sámi as indigenous people. ${ }^{40}$

The first legal definition of Sámi in Finland from 1973 relied heavily on knowledge of the Sámi language, as it required, in addition to self-identification with the Sámi people, that at least one of the person's parents or grandparents had learned Sámi as their first language. In 1995 the legal definition was amended despite the Sámi Parliament's objection, recognizing also those who are descendant of someone who has been registered as Fell, Forest or Fishing Sámi in the land taxation or census registers. From there on the law contained a discrepancy regarding historical reach of the criteria: the language criteria extends to grandparents, whereas the register criteria is not temporarily limited in the law, albeit the criteria has been restricted in legal practice usually to registers of 1870 with a few exceptions. ${ }^{41}$ According to the current Act on the Sámi Parliament a person is considered a Sámi if they consider themselves a Sámi and if 1) they themselves or at least one of their parent or grandparent has learned Sámi as the first language or 2) they are descendant of someone who has been registered as a Fell, Forest or Fishing Sámi in the land taxation or census register or 3) at least one of their parents has or could have been registered as entitled to vote in the elections of the Sámi Delegation or the Sámi Parliament.

\footnotetext{
${ }^{38}$ Leena Heinämäki, 'Saamelaismääritelmä kansainvälisen oikeuden ja KHO:n tapausten valossa' in Leena Heinämäki et al. (eds), Saamelaisten oikeuksien toteutuminen: kansainvälinen oikeusvertaileva tutkimus (Prime Minister's Office Publications 2017) 87-8.

${ }^{39}$ More than half of the Sámi in Finland live outside of the Sámi homeland area.

${ }^{40}$ However in practice the authorities have interpreted this provision as an obligation to consult the Sámi rather than to negotiate with them. See for example John B. Henriksen, 'The continuous process of recognition and implementation of the Sami people's right to self-determination' (2008) 21:1 Cambridge Review of International Affairs 27, 31—2; Laura Junka-Aikio, 'Can the Sámi speak now? Deconstructive research ethos and the debate on who is a Sámi in Finland' (2016) 30:2 Cultural Studies 205, 214.

${ }^{41}$ Veli-Pekka Lehtola, Saamelaiskiista: Sortaako Suomi alkuperäiskansaansa? (Into, 2015) 61—2, 65, 68, 69.
} 
The question of who is Sámi is debated on many fronts in Finland. Academically this debate has surfaced as a question of whether or not there is a group of people (non-status Sámi) who should be recognized as Sámi due to their ancestry and identification with the Sámi culture as well as their role as revivers of the Sámi languages, ${ }^{42}$ or whether the idea of non-status Sámi is in fact related to attempts to undermine the Sámi rights. ${ }^{43}$ The fear is that 'the extension of the Sámi definition would lead to a takeover of Sámi political and cultural institutions by people whose links to Sámi culture and community are extremely distant or even non-existent'. ${ }^{44}$ Therefore the Sámi Parliament has argued in favor of narrowing the legal definition of Sámi by removing or modifying the clause concerning linkage to old state registers and instead emphasized the importance of real and living connection to the Sámi community.

Ultimately in Finland the question of who is Sámi - that is, who is accepted in the Sámi Parliament's electoral roll - is decided by the Supreme Administrative Court. Thus the Sámi Parliament does not have the final say over who is officially recognized as Sámi. ${ }^{45}$ Until 2011 the Supreme Administrative Court emphasized the language criteria along with the autonomy of the Sámi people to determine who is recognized as Sámi. In 2011 the Court changed its line of argumentation by introducing overall assessment of the legal criteria of the eligibility for the Sámi electoral roll. ${ }^{46}$ The Court decided that despite the lack of sufficient evidence in favor of applying any of the three criterion individually, the applicant could be recognized as Sámi due to the evidence they provided of their ancestry and their strong identification with the Sámi people. ${ }^{47}$

The inherent tension of the question who is indigenous is reflected not only in the domestic case law of the Finnish courts, but also in the recommendations by the UN Committee on the Elimination of Racial Discrimination (CERD): both attempt to balance the individual and group interests. The Supreme Court's ruling in 2011 followed the CERD recommendation in 1990 stating that 'the ways in which individuals are identified as being members of a particular racial or ethnic

\footnotetext{
${ }^{42}$ Tanja Joona, ILO Convention No. 169 in a Nordic Context with Comparative Analysis: An Interdisciplinary Approach (University of Lapland 2012); Erika Sarivaara, Satu Uusautti and Kaarina Määttä, 'The Position and Identification of the Non-Status Sámi in the Marginal of Indigeneity' (2013) 13:1 Global Journal of Human Social Science Arts and Humanities 23.

${ }^{43}$ Laura Junka-Aikio, 'Can the Sámi speak now? Deconstructive research ethos and the debate on who is a Sámi in Finland' (2016) 30:2 Cultural Studies 205.

${ }^{44}$ See ibid. 215; see also Sébastien Grammond, Identity Captured by Law. Membership in Canada's Indigenous Peoples and Linguistic Minorities (McGill-Queen's University Press 2009).

${ }^{45}$ Laura Junka-Aikio, 'Can the Sámi speak now? Deconstructive research ethos and the debate on who is a Sámi in Finland' (2016) 30:2 Cultural Studies 205, 216-8, 220-3.

${ }^{46}$ Leena Heinämäki et al. (eds), Saamelaisten oikeuksien toteutuminen: kansainvälinen oikeusvertaileva tutkimus (Prime Minister's Office Publications 2017); Supreme Administrative Court of Finland T 271026 September 2011.

${ }^{47}$ Supreme Administrative Court of Finland 2011:81.
} 
group' shall, 'if no justification exists to the contrary, be based upon self-identification by the individual concerned'. ${ }^{48}$

However, in 2012 the CERD updated its recommendation now emphasizing the right to selfdetermination of the Sámi people. ${ }^{49}$ While noting that in its ruling in 2011 the Finnish Supreme Administrative Court relied on the Committee's recommendation made in 1990, the Committee expressed its concern that the Court's approach gives insufficient weight to the Sámi people's rights, in particular their right to determine their own identity or membership in accordance with their customs and traditions as well as their right not to be subjected to forced assimilation or destruction of their culture. The committee recommended that in defining who is eligible to vote for members of the Sámi parliament, the state party accord due weight to the right of the Sámi people to self-determination.

Despite the Supreme Administrative Court acknowledged this new recommendation, it did not adopt it in its recent case law, in which the Court re-established the overall assessment of the legal criteria. ${ }^{50}$ Overruling the decision of the Sámi Parliament, the Court gave a number of rulings in 2015 accepting 93 people out of 182 applicants to be registered in the electoral register. ${ }^{51}$ In 53 cases out of the 93 the Court applied overall assessment, and 21 of those were favorable to applicants whose applications the Court had rejected in 1999. ${ }^{52}$ Many of the cases deal with the question of evidence of Sámi lineage. For example in one of the cases the Court decided that despite the applicant not being able to reliably prove their ancestry or the mother tongue of their parents as required by the law, the overall assessment of the evidence provided by the applicant of their lineage, their traditional way of life and the fact that they self-identified as Sámi, led to the conclusion that they should be registered as Sámi, despite the Sámi Parliament's objection. ${ }^{53}$

The Court's decision was not easily accepted by the Sámi Parliament which decided to reorganize the recent elections without including the newly enfranchised. ${ }^{54}$ Furthermore the Estonian member

\footnotetext{
${ }^{48}$ U.N. Doc. A/45/18 at 79.

49 CERD/C/FIN/CO/20-22; Leena Heinämäki, 'Saamelaismääritelmä kansainvälisen oikeuden ja KHO:n tapausten valossa' in Leena Heinämäki et al. (eds), Saamelaisten oikeuksien toteutuminen: kansainvälinen oikeusvertaileva tutkimus (Prime Minister's Office Publications 2017) 89—90.

${ }^{50}$ Leena Heinämäki, 'Saamelaismääritelmä kansainvälisen oikeuden ja KHO:n tapausten valossa' in Leena Heinämäki et al. (eds), Saamelaisten oikeuksien toteutuminen: kansainvälinen oikeusvertaileva tutkimus (Prime Minister's Office Publications 2017) 90, 144.

${ }^{51}$ See for example Supreme Administrative Court of Finland decisions 2015:145; 2015:146; 2015:147; $2015: 148$.

${ }^{52}$ Leena Heinämäki, 'Saamelaismääritelmä kansainvälisen oikeuden ja KHO:n tapausten valossa' in Leena Heinämäki et al. (eds), Saamelaisten oikeuksien toteutuminen: kansainvälinen oikeusvertaileva tutkimus (Prime Minister's Office Publications 2017) 108, 121, 138.

${ }^{53}$ Supreme Administrative Court of Finland 2015:147.

54 'Saamelaiskäräjien hallitus: vaalit uusiksi' (Enontekiön Sanomat 25 November 2015)

http://www.enontekionsanomat.fi/arkisto/saamelaiskarajien-hallitus-vaalit-uusiksi.html accessed 7 May 2018.
} 
of the UN Permanent Forum on Indigenous Issues, Oliver Loode, urged the Sámi Parliament to consider suspending the elections due to the controversial Court decision. According to him, the decision is contrary to the principles of the UN Declaration on the Rights of Indigenous Peoples to which Finland is committed, and that according to those principles 'Sáminess should be decided by the Sámi Parliament, not the Supreme Administrative Court'. ${ }^{55}$ Moreover, the former chairman of the Sámi Parliament, Klemetti Näkkäläjärvi, requested to be removed from the Sámi electoral register as he felt that the Court's interpretation of who is Sámi did not correspond with that of the Sámi Parliament. According to him, the Sámi community does not recognize the newly enfranchised as Sámi, and that the Finnish state, the law and the Supreme Administrative Court of Finland do not respect the cultural, historical and legal rights of the Sámi. ${ }^{56}$

In 2014 the Finnish Government introduced a proposal supported by the Sámi Parliament that would have changed the legal criteria for recognizing someone as Sámi in the electoral register. ${ }^{57}$ The new criteria would have emphasized the individual's bond to, and recognition by the Sámi community, and removed the possibility to be registered as Sámi on the grounds of being a descendant of someone registered as Sámi in old land taxation and census registers. ${ }^{58}$ The Sámi Parliament also advocated for removing the possibility to appeal to the Supreme Administrative Court on the Sámi Parliament's decisions concerning the register. ${ }^{59}$

The bill was withdrawn in March 2015 due to lack of sufficient support for narrowing the Sámi definition within the Parliament. It is expected that the matter resurfaces now that the Nordic Sámi Convention has been agreed and signed upon in 2017 after a decade of negotiations. The Convention includes a co-Nordic provision on the right to vote in the elections to the Sámi Parliament, which would, on one hand, extend the mother-tongue criterion one generation further in history, but remove the land taxation and census register criterion, on the other hand. The Convention safeguards the Sámi people's constitutional right to maintain and develop their own language and culture. It does not, however, bring changes to the Sámi rights to land and water in the

\footnotetext{
55 'UN representative urges to consider suspension of Sámi elections' (Yle News 1 October 2015) https://yle.fi/uutiset/osasto/news/un_representative_urges_to_consider_suspension_of_sami_elections/8348127 accessed 7 May 2018.

56 'Ex- Sámi Parliament head quits voter's register, calls Finland "a racist country"' (Yle News 30 September 2015) https://yle.fi/uutiset/osasto/news/ex-

_sami_parliament_head_quits_voters_register_calls_finland_a_racist_country/8344761 accessed 7 May 2018.

${ }_{57}$ Government bill 167/2014.

${ }^{58}$ Ibid.

${ }^{59}$ Leena Heinämäki, 'Saamelaismääritelmä kansainvälisen oikeuden ja KHO:n tapausten valossa' in Leena Heinämäki et al. (eds), Saamelaisten oikeuksien toteutuminen: kansainvälinen oikeusvertaileva tutkimus ((Prime Minister's Office Publications 2017) 157; Veli-Pekka Lehtola, Saamelaiskiista: Sortaako Suomi Alkuperäiskansaansa? (Into 2015) 84, 185.
} 
homeland area, despite securing the Sámi opportunities to participate in the planning, management and use of the land and water. ${ }^{60}$

\section{The courts' role: implicit and explicit}

Belonging is always a dynamic process which includes both self-identification and recognition by others. Moreover, belonging does not imply only a certain category of social location, but also a certain positionality along an axis of power. ${ }^{61}$ In other words, the fluid, constantly changing and contested categories of belonging locate people differently on the social hierarchy. The concrete social location of an individual is constructed along intersecting social divisions that do not simply add up, but rather define each other. ${ }^{62}$ According to Yuval-Davis, struggles for recognition always include an element of construction. She understands identities as stories people tell, individually or collectively, to themselves and others about who they are - and who they are not. ${ }^{63}$ Any abstract form of community, such as the nation state, is necessarily based on an abstract sense of imagined simultaneity, and that any construction of belonging that includes some people, excludes others. ${ }^{64}$ The debates surrounding this 'boundary maintenance' between 'us' and 'the Other' are often about the minimum requirements of belonging in 'us' in terms of values, culture and origin, as well as loyalty and solidarity towards the collectivity. ${ }^{65}$

According to Yuval-Davis some requisites of belonging, such as origin and the place of birth are most racialized and least permeable, while others, such as language, culture and religion are more open to voluntary identification. However, these dimensions of belonging can be collapsed together in such a way that they cannot be separated from each other. ${ }^{66}$ The case of S.A.S v. France illustrates such collapsing in that it shows how the boundaries of 'true' belonging in the French community is negotiated in legal proceedings. The applicant in S.A.S contested the social hierarchy in which she as a Muslim woman covering her face in public was regarded as a threat to 'living

\footnotetext{
60 'Submission by the National Human Rights Institution of Finland, the Human Rights Centre for the UN Committee on the Elimination of Racial Discrimination before the examination of Finland' (The Finnish Human Rights Center 3 April 2017) https://www.ihmisoikeuskeskus.fi/@Bin/4623423/CERD-FINLAND\%20-\%20NHRI\%20contribution\%202017final.pdf accessed 7 May 2018.

${ }^{61}$ Nira Yuval-Davis, 'Belonging and the politics of belonging' (2006) 40:3 Patterns of Prejudice 197, 199.

62 Ibid. 200.

${ }^{63}$ Ibid. 201-2.

${ }^{64}$ Ibid. 204. See also Benedict Anderson, Imagined Communities (Rev. ed. Verso 2006).

${ }^{65}$ Nira Yuval-Davis, 'Belonging and the politics of belonging' (2006) 40:3 Patterns of Prejudice 197, $207,209$.

66 Ibid. 209.
} 
together'. She, on the other hand, attempted to tell a different story of who and what is French by challenging the othering and racializing logic of the full-face veil ban. The case illustrates the role of the European Court of Human Rights in implicitly drawing the boundaries of belonging. On the surface the Court was weighing and balancing the personal freedoms enshrined in the Convention against the competing interests of the society. At the same time, however, the Court implicitly and indirectly participated in the debate over the French citizen subject.

In the second example concerning the question of officially belonging to the Sámi people, the role of the Finnish Administrative Court was explicit regarding belonging, as it determined whether or not the applicants should be registered in the Sámi Parliament electoral roll. In Finland the Sámi entering the global indigenous peoples' movement and the internationalization of the Sámi movement since 1970's was met with increasing tension and a shift from cautious minority policy of concessions and conflict avoidance towards more hostile policy. ${ }^{67}$ According to Nyyssönen 'a paternalistic undercurrent ensued which absorbed the Sámi into the Finnish national whole by referring to the formal equality that citizenship provided' ${ }^{68}$ Thus the struggle of the Sámi is opposite to the applicant in S.A.S.; they resist losing their indigenous identity by assimilation, whereas the French Muslims woman covering her face invites the French society to recognize her as one of 'us' and thus redefine the French citizen subjectivity.

The fear of disintegration of the nation and of the national identity seems to underlie both examples discussed in this Chapter, although from opposite points of view. The cases concerning the Islamic full-face veil illustrate the fear of 'foreign' Muslim elements diluting the French identity and eroding the sense of belonging in the society, and the struggle of the Sámi for recognition as an indigenous people has raised fears over separatism and disintegration of the nation state. ${ }^{69}$ The individual struggles for being recognized as Sámi relate on one hand to sensitive questions of selfidentification with the indigenous people that resonate with the painful past of assimilation and discrimination on one hand, and to that of the protecting the distinct identity of the indigenous people from being effaced, on the other hand. Both examples raise similar questions concerning rights, identity, recognition and belonging, and the courts' role in drawing the boundaries between 'us' and 'the Other'.

\footnotetext{
${ }^{67}$ Jukka Nyyssönen, 'Between the Global Movement and National Politics: Sami Identity Politics in Finland from the 1970s to the early 1990s'in Henry Minde (ed.), Indigenous Peoples: Self-Determination Knowledge Indigeneity (Eburon Academic Publishers 2008) 87.

${ }^{68}$ Ibid. 89.

69 Ibid.
} 


\section{Table of cases}

European Court of Human Rights
Ahmet Arslan v Turkey App no 41135/98 (ECHR 23 February 2010)
Balkacemi and Oussar v Belgium App no 37798/13 (ECHR 11 July 2017)
Dahlab v Switzerland ECHR 2001-V
Dakir v. Belgium App no 4619/12 (ECHR 11 July 2017)
Eweida and others v The United Kingdom ECHR 2013.
Lautsi v Italy ECHR 2011
Leyla Şahin v Turkey ECHR 2005-XI

Supreme Administrative Court of Finland

T 271026 September 2011

2011:81

2015:145

2015:146

2015:147

2015:148

\section{International Conventions and Documents}

International Labour Organization C169 Convention concerning Indigenous and Tribal Peoples in Independent Countries (No. 169) (5 September 1991)

United Nations Declaration on the Rights of Indigenous Peoples (A/RES/61/295) Resolution adopted by the General Assembly on 13 September 2007 
Committee on the Elimination of Racial Discrimination U.N. Doc. A/45/18 at 79 General Recommendation 8: Membership of racial or ethnic groups based on self-identification (Thirty-eighth session, 1990).

Committee on the Elimination of Racial Discrimination CERD/C/FIN/CO/20-22 Concluding observations on the combined twentieth to twenty second periodic reports of Finland 


\section{Bibliography}

- - Ex-Sámi Parliament head quits voter's register, calls Finland "a racist country" (Yle News 30 September 2015) https://yle.fi/uutiset/osasto/news/ex-

_sami_parliament_head_quits_voters_register_calls_finland_a_racist_country/8344761

- - 'Saamelaiskäräjien hallitus: vaalit uusiksi' (Enontekiön Sanomat 25 November 2015) http://www.enontekionsanomat.fi/arkisto/saamelaiskarajien-hallitus-vaalit-uusiksi.html

- - 'Submission by the National Human Rights Institution of Finland, the Human Rights Centre for the UN Committee on the Elimination of Racial Discrimination before the examination of Finland' (The Finnish Human Rights Center 3 April 2017)

https://www.ihmisoikeuskeskus.fi/@Bin/4623423/CERD-FINLAND\%20-

$\% 20$ NHRI\%20contribution\%202017-final.pdf

- - 'UN representative urges to consider suspension of Sámi elections' (Yle News 1 October 2015) https://yle.fi/uutiset/osasto/news/un_representative_urges_to_consider_suspension_of_sami_electio ns/8348127

Akan M, 'Laïcité and multiculturalism: the Stasi Report in context' (2009) 60(2) The British Journal of Sociology 237

Chaib, SO and Peroni L, 'S.A.S. v. France: Missed Opportunity to Do Full Justice to Women Wearing a Face Veil' (Strasbourg Observers, 3 July 2014)

https://strasbourgobservers.com/2014/07/03/s-a-s-v-france-missed-opportunity-to-do-full-justice-towomen-wearing-a-face-veil/ accessed 19 October 2017

Chartrand, L., 'Re-Conceptualizing Equality: A Place for Indigenous Political Identity' (2001) 19 Windsor Yearbook of Access to Justice (2001) 243.

Chrisafis A, 'French burkini ban row escalates after clothing incident at Nice beach' The Guardian (25 August 2016) https://www.theguardian.com/world/2016/aug/24/french-burkini-ban-rowescalates-clothing-incident-woman-police-nice-beach accessed 19 October 2017.

Daly E, 'Laicite in the Private Sphere? French Religious Liberty After the Baby-Loup Affair' (2016) 5 Oxford Journal of Law and Religion 211. 
Dearden L, 'Austrian parliament passes burqa ban seeing Muslim women face $£ 130$ fines for wearing full-face veils' Independent (18 May 2017)

http://www.independent.co.uk/news/world/europe/austria-burqa-ban-parliament-fines-150-fullface-veils-muslim-islam-niqabs-public-transport-a7742981.html accessed 19 October 2017.

Evans C, 'The Islamic Scarf' in the European Court of Human Rights' (2006) 7(1) Melbourne Journal of International Law 52

Ferri M, 'Belkacemi and Oussar v Belgium and Dakir v Belgium: the Court again addresses the full-face veil, but it does not move away from its restrictive approach' (Strasbourg Observers 25 July 2017) https://strasbourgobservers.com/2017/07/25/belkacemi-and-oussar-v-belgium-and-dakirv-belgium-the-court-again-addresses-the-full-face-veil-but-it-does-not-move-away-from-itsrestrictive-approach/\#more-3838.

Fokas E 'Directions in Religious Pluralism in Europe: Mobilizations in the Shadow of European Court of Human Rights Religious Freedom Jurisprudence' (2015) 4(1) Oxford Journal of Law and Religion 54.

Garner S and Selod S, 'The Racialization of Muslims: Empirical Studies of Islamophobia' (2015) 41:1 Critical Sociology 9.

Gaski L, 'Sami Identity as a Discursive Formation: Essentialism and Ambivalence' in Henry Minde (ed.), Indigenous Peoples: Self-Determination Knowledge Indigeneity (Eburon Academic Publishers 2008).

Grammond, S, Identity Captured By Law: Membership in Canada's Indigenous Peoples and Linguistic Minorities (McGill-Queen's University Press 2009).

Heinämäki L, 'Saamelaismääritelmä kansainvälisen oikeuden ja KHO:n tapausten valossa' in Leena Heinämäki et al.(eds.) Saamelaisten oikeuksien toteutuminen: kansainvälinen oikeusvertaileva tutkimus (Prime Minister's Office Publications 2017).

Heinämäki L et al. (eds.) Saamelaisten oikeuksien toteutuminen: kansainvälinen oikeusvertaileva tutkimus (Prime Minister's Office Publications 2017)

Henriksen JB, 'The continuous process of recognition and implementation of the Sami people's right to self-determination' (2 008) 21:1 Cambridge Review of International Affairs 27. 
Hunter-Henin M, 'Why the French don't like the burqa: Laïcité, national identity and religious freedom’ (2012) 61(3) International \& Comparative Law Quarterly 613

Joona T, ILO Convention No. 169 in a Nordic Context with Comparative Analysis: An Interdisciplinary Approach (University of Lapland 2012).

Junka-Aikio L, 'Can the Sámi speak now? Deconstructive research ethos and the debate on who is a Sámi in Finland' (2016) 30:2 Cultural Studies 205.

Laegaard S, 'Burqa Ban, Freedom of Religion and "Living Together"' (2015) 16(3) Human Rights Review 203.

Lehtola V-P, Saamelaiskiista: Sortaako Suomi Alkuperäiskansaansa? (Into, 2015).

Martinez Cobo JR, 'Study of the problem of discrimination against indigenous populations' Volume 1, E/CN.4/Sub.2/1986/7.

Mills CW, The Racial Contract (Cornell University Press 1999).

Mullally S, 'Gender equality, citizenship status, and the politics of belonging' in Martha Albertson Fineman (ed.) Transcending the boundaries of law. Generations of feminism and legal theory (Routledge 2011) 201

Nieminen K, 'Disobedient subjects - constructing the subject, the state and religion in the European Court of Human Rights' (2015) Social Identities 21.

_- The Law, the Subject and Disobedience - Inquiries into Legal Meaning Making (University of Helsinki 2017).

_ - 'Procedural and De-Contextualised Approach to Discrimination in the European Court of Human Rights: The Case of S.A.S. v France' (2018) Unpublished manuscript.

Nyyssönen J, 'Between the Global Movement and National Politics: Sami Identity Politics in Finland from the 1970s to the early 1990s'in Henry Minde (ed.), Indigenous Peoples: SelfDetermination Knowledge Indigeneity (Eburon Academic Publishers 2008).

Omi M and Winant H, Racial Formation in the United States: From the 1960s to the 1990s (Routledge 1986). 
Razack S, 'Imperilled Muslim Women, Dangerous Muslim Men and Civilised Europeans: Legal and Social Responses to Forced Marriages’ (2004) 12 (2) Feminist Legal Studies 129.

Razack S, Casting Out: The Eviction of Muslims from Western Law and Politics (University of Toronto Press 2008).

Said EW, Orientalism: Western Conceptions of the Orient (Penguin Books 1995).

Simon P and Sala Pala V, "We are not all multiculturalists yet" France swings between hard integration and soft anti-discrimination' in Steven Vertovec and Susanne Wessendorf (eds) The Multiculturalism Backlash. European discourses, policies and practices (Routledge 2010).

Sarivaara E, Määttä K and Uusautti S, 'Who Is Indigenous? Definitions of Indigeneity’ (2013) 1 SE European Scientific Journal 369.

Sarivaara E, Uusautti S and Määttä K, 'The Position and Identification of the Non-Status Sámi in the Marginal of Indigeneity' (2013) 13:1 Global Journal of Human Social Science Arts and Humanities 23.

Selod S and Embrick DG, 'Racialization and Muslims: Situating the Muslim Experience in Race Scholarship' 2013) 7:8 Sociology Compass 644.

Taub A, 'France's 'Burkini' Bans Are about More than Religion or Clothing' The New York Times (18 August 2016) https://www.nytimes.com/2016/08/19/world/europe/frances-burkini-bans-areabout-more-than-religion-or-clothing.html accessed 19 October 2017.

Thomas ER, Immigration, Islam, and the Politics of Belonging in France: A Comparative Framework (University of Pennsylvania Press 2011).

Vauchez SH, 'Is French laïcité Still Liberal? The Republican Project Under Pressure (2004-15)' (2017) 17 Human Rights Law Review 285.

Yuval-Davis N, 'Belonging and the politics of belonging' (2006) (40:3) Patterns of Prejudice 197. 